\title{
NGO EFFECTIVENESS: EVIDENCE FROM THE FieLd OF CHILd LABOUR IN El SALVADOR Ivica Petrikova, UCL
}

\author{
Forthcoming in Forum for Development Studies
}

Abstract

This paper examines the impact that mutual relations among three non-governmental organizations (NGOs) working with child labourers in El Salvador have on the overall effectiveness of their development assistance. One of the organizations examined leans towards an 'adaptive' approach to child labour, seeing the issue as an inevitable consequence of poverty that cannot be tackled separately from addressing other developmental problems. Another of the organizations advocates the use of an 'abolitionist' approach to child labour, regarding child labour as a direct violation of children's rights and hence morally wrong and in need of immediate abolition. The third organization falls in its approach somewhere in the middle of the spectrum, advocating strictly against child labour in theory but providing more realistic solutions in its actual work.

My findings on the collective effect of the NGOs' work on child labour in El Salvador are not particularly encouraging. The organizations under study appear to neither collaborate nor greatly communicate with each other. Moreover, since their adopted approaches to child labour are at cross-purposes, they are essentially annulling each other's efforts. I conclude with the observation that in order to increase their aid effectiveness, NGOs working in child labour, and in other divisive development topics, should be in closer coordination with each other as well as with the governments of the countries where they work.

Keywords: NGOs, aid effectiveness, child labour, Central America, El Salvador 


\section{Introduction}

Mainstream economic theory suggests that perfect competition among suppliers is the most effective manner of delivering goods and services, with government interventions generating usually undesirable market distortions. The aid market constitutes from this viewpoint somewhat of an exception, however. While some researchers believe that the fact that aid is provided by a myriad of different donors is positive as it begets more innovation and creative solutions, others highlight the possibility that donor proliferation without coordination weakens the overall impact of aid and potentially even harms the aid recipients. As a result of this concern, several high-level international initiatives aimed at improving donor coordination have taken place recently, including among others the Paris Declaration on Aid Effectiveness (2005) and the Accra Agenda for Action (2007). These initiatives were, however, directed primarily at official multilateral and bilateral aid agencies, not at nongovernmental actors active in development assistance.

Non-governmental organizations (NGOs) have become in the recent years ever more popular vehicles for delivering development assistance (McCoskey 2009). The aid that they provide is not formally coordinated either but this reality is not regarded equally problematic since in comparison to official donors, NGOs are seen as more virtuous players due to a lack of political and economic interests that could befuddle their charitable ones. The necessity to formally coordinate NGO aid is further downplayed by the fact that most NGOs implement projects on a much smaller scale and in closer cooperation with local beneficiaries than official donors and hence are seen as directly and easily accountable to their 'clients.' This paper investigates on a case-study of NGOs working in the field of child labour in $\mathrm{El}$ Salvador whether these premises indeed hold true: what the nature of interaction among development NGOs working in this relatively controversial area is and how it is likely affecting the overall impact of their development projects. 


\section{Literature Review}

This section first introduces existing research regarding aid coordination both on the official and on the non-governmental level. It proceeds with a discussion of the issue of child labour, first globally and second specifically in El Salvador. Finally, it finishes with an identification of theoretical gaps to which my paper attempts to provide a contribution.

\section{II.1 Aid coordination}

It has been a well-known fact that the number of official donors and of their programs and projects in the developing world has been rising ever since the 1970s (Knack and Rahman 2004). In the 2000s, however, the state of aid proliferation and fragmentation reached truly astonishing levels. According to Acharya et al. (2003), between 1999 and 2001, only four out of the total 22 Development Assistance Committee (DAC) donors were providing official development assistance to fewer than 90 recipients. In order to further illustrate the state of the situation, the authors mentioned the example of Vietnam, where in that time period 25 official bilateral donors, 19 official multilateral donors, and 350 international NGOs operated a grand total of 8000 development projects, one per every 9000 people.

Researchers generally agree that donor fragmentation and lack of coordination negatively impact aid recipients. Morss (1984) was perhaps the first author to point out that the dramatic increase in the number of development projects in sub-Saharan Africa in the 1970s had a harmful effect on the recipients' institutions. Rather than identifying national development goals in line with populations' needs, developing countries' governments concentrated on accommodating the myriad of new donors and their various requirements instead. Knack and Rahman (2004) confirmed this view, demonstrating that the high number of donors working in most developing countries tends to weaken the countries' administrative capacity. The underlying reason is that most donors focus only on maximizing their own projects' 
performance and disregard the development of the recipients' human and organizational structures, which are, nonetheless, essential to long-term growth.

Bigsten (2006) and Lawson (2010) added to the list of afflictions caused by donor proliferation and lack of coordination high transaction costs, duplication, and a loss of scale. The transaction costs involve the time and energy spent on dealing with paperwork for all the different development projects, which significantly increase with the number of projects regardless of their size (Bigsten 2006). Duplication refers to the distinct possibility that uncoordinated donors provide the same services in some sectors while none in others (Lawson 2010). Finally, vis-à-vis the loss of scale, non-cooperating individual donors tend to conduct predominantly smaller projects and only a few have the resources to undertake larger schemes such as energy and infrastructure improvements (Lawson 2010).

Nevertheless, Frot and Santiso (2010), while not disputing that fragmented, uncoordinated aid can be harmful to the recipient countries, warned about too little donor competition. In case one donor dominates all the aid provided to one sector in any developing country, the aid is in their view unlikely to be provided in the most efficient manner possible. Moreover, a more numerous range of donors can beget more ideas, competition, and innovation, as well as represent a more consistent flow of funding (Lawson 2010).

The international aid community eventually responded to the great increase in the number of donors and projects in the developing world with several high-level efforts at increasing aid effectiveness, with improving donor coordination and harmonization among the chief goals. The first initiative was the establishment of the DAC Working Party on Aid Effectiveness (2003), followed by the Paris Declaration on Aid Effectiveness ${ }^{1}$ (2005). In it, more than hundred countries and aid agencies agreed to improve donor division of labour via an increased use of common arrangements and procedures and of shared analysis. The Accra

\footnotetext{
${ }^{1}$ Result of a High Level Forum on Aid Effectiveness in Paris in 2005
} 
Agenda for Action (2008) reiterated these objectives, albeit in a slightly less authoritative tone.

All the initiatives mentioned pertained primarily to official donors, however, not to NGOs working in development aid. That is not to say that the NGO sector was believed to be wellcoordinated already and therefore no efforts in that regard were needed. Rather, the predominant view has been that the potential lack of coordination among NGOs is less problematic than among official donor agencies and consequently that it does not require the same level of attention.

The underlying reasons are twofold. First, NGOs are not believed to be motivated by political motives to the same extent as states (Easterly 2002, McCoskey 2009). Thus, the aid that they provide is more likely to be extended out of true solidarity, not out of the desire to influence the recipients' policies, and the well-being of the aid recipients are more likely to be truly considered before the projects' implementation. Second, NGOs generally operate small development projects that serve only subgroups of the countries' populations and hence their need to coordinate with other NGOs serving other subgroups in a different part of the country are not as pressing as with official donors' country-wide projects (McCoskey 2009). An extra advantage to the NGOs' smaller size is their greater efficiency due to lower bureaucratic and administrative costs (Scott and Hopkins 1999).

Empirical research on mutual NGO relations and on their effect on overall aid effectiveness has yielded mixed results. Some authors found NGO aid to be highly discordant and thus ineffective or even disruptive of the desired development goals (Oxfam 2000). For example, in examining the impact of NGO work on public health services in Mozambique, Pfeiffer (2003) concluded that the deluge of NGOs and expatriate health workers in the 1990s fragmented the local health care system and undermined local control of health programs. Another famous case of deficient NGO coordination has been in the aftermath of the 2005 
tsunami in South-East Asia, which was followed by an inundation of well-meaning but often effort-duplicating humanitarian NGOs (Telford and Cosgrave 2007). Nevertheless, other authors found the existing state of NGO coordination to be relatively satisfactory (Edi and Setianingtias 2007, Moore et al. 2003, Ohler and Nunnenkamp 2012). Paris and Sisk (2009) along with Volz (2005) even warned that too-close coordination efforts among NGOs could result in the adoption of de-contextualized development approaches, not sufficiently tailored to specific local conditions.

\section{II.2 Child labour in the world}

The International Labour Organization (ILO) defines child labour as any work that deprives children of their childhood, their potential and their dignity, and that is harmful to their physical and mental development. According to the ILO's latest estimates, currently there are 215 million child labourers worldwide, primarily in the developing world. Many of the children work full-time and do not attend school. Approximately two-thirds work in agriculture and one third is younger than 12 years. Only one out of each five child labourers works in paid employment (ILO 2013).

Child labour was highly prevalent throughout the industrialized world as well until the beginning of the $20^{\text {th }}$ century, when a combination of economic improvements and legislation brought about for the most part its elimination. This development was followed by a series of international initiatives aimed at eradicating child labour everywhere. In 1978, the ILO passed a Minimum Age Convention (no. 138), which fixed the minimum age at which children were allowed to work at 15 (14 in developing countries). In 1999 the ILO followed with The Worst Forms of Child Labour Convention (no. 182), which stipulated that only children older than 17 years could work in certain specified 'hazardous' forms of work. Other 
international conventions, most notably the UN Convention on the Rights of the Child, also bound their signatories to do away with child labour.

The agreement that child labour is undesirable is almost universal; however, the views about how it should be best tackled are highly divergent. On one side of the spectrum lie those who perceive the phenomenon to be an inevitable consequence of poverty - a so-called 'adaptive' approach - and do not advocate for much specific intervention. For example, Dessy and Pallage (2004) disagree with the ILO legislation against child labour, even with the ban on the worst forms of child labour, claiming that parents who send their children to dangerous mines or to prostitution generally make a rational economic choice. In the authors' view, a ban on such behaviour attempts to cure only the symptoms, not the causes of the problem, and thus is counterproductive. In a similar manner, Swinnerton and Rogers (1999) see child labour as an issue that should not be addressed through legislation and bans but rather through intra-country redistribution of wealth by progressive taxation and social welfare programs. Some authors falling within this field of thought even posit that child labour is not always negative as it helps build character by teaching punctuality, discipline, and rigor (Ray 2000 cited in Dessy and Pallage 2004).

On the opposite side of the spectrum lie the so-called 'abolitionists', who regard all child labour to be in dire violation of children's human rights and hence morally wrong and in need of immediate elimination. Researchers and practitioners who adhere to this view generally support stronger child-labour legislation, both on the national and international levels, along with trade sanctions and boycotts to be used against countries and products that employ child labour. The economic argument underlying this line of thinking maintains that there are two possible market equilibriums in each economy where child labour is utilized -- one with children working and their parents receiving low wages and the other one with children not working and their parents' wages higher, by an amount sufficient to compensate for the lack 
of children's income (Basu and Van 1998). From this perspective, an effectively enforced ban on child labour would resolve the problem in question in a short matter of time. Other researchers provide support for the abolitionist approach from a different angle -- they find that children from families with larger amounts of land or family businesses tend to actually work more than children from the poorest families, and thus a ban or alternatively awarenessraising could put an end to child labour even without changing the families' economic situation (Bhalotra and Heady 2003, Deb and Rosati 2004).

Most development practitioners who work with child labour fall somewhere in between the two extreme sides of the spectrum. Nevertheless, they do tend to lean more to one side or the other. Organizations that are closely associated with the ILO, for instance, tend to advocate for a more abolitionist approach, while local organizations might likely focus more on the economic side of the problem.

\section{II.3 Child labour in El Salvador}

Turning to the specific case of El Salvador, currently there are approximately 170,000 child labourers in the country, which constitutes nine per cent of all children between five and 17 years of age (US Department of Labour [DoL] 2012). Only one per cent of children between five and nine years old work, whereas 10.5 per cent of children between 10 and 14 and 23.8 percent of 15 to 17 year olds do so. 60 per cent of the working children live in rural areas and 73 per cent are boys. Only 50 per cent of the Salvadoran child labourers work in agriculture, as opposed to 60 per cent at the global level. 60 per cent of Salvadoran child labourers combine work with school and around 35 per cent receive some form of remuneration - again, in contrast with only 20 per cent at the global level. While there has been a reduction in the amount of child labour in the early 2000s, in 2009 - the last year for which data is thus far available - there has been an increase in the number of child labourers 
compared to 2007, undoubtedly as a consequence of the global economic crisis (Salvadoran Ministry of Economy [MINECON] 2010).

The Salvadoran government signed and ratified all three of the most important childlabour conventions discussed - the UN Convention on the Rights of the Child as well as the two ILO child-labour conventions, no. 138 and no. 182. The prohibition on any child work prior to age 14 (12 in circumstances of extreme poverty) and on hazardous work prior to age 18 has been grounded also in national law. In reality, however, the country has been for many years criticized by the ILO and other international bodies for failing to enforce the existing child labour legislation, particularly in the five sectors identified as the "worst forms of child labour' in El Salvador: sugar cane cultivation, mollusk collection, trash collection, fireworks production, and prostitution. In their most recent reports, the ILO and the DoL extended some praise to the Salvadoran government for the new Let's Go to School program, which provides free meals, textbooks, and uniforms to poor children and thus aims to reduce the incidence of child labour. Nevertheless, in the view of both the institutions, many problems with the approach to child labour in the country still remain, particularly with enforcing the existing prohibitions on children under 18 working in the 'worst forms of child labour'.

Aside from the national government, international organizations, and official aid agencies, non-governmental development organizations are also actively dealing with the issue of child labour in El Salvador. According to the ILO, only 12 NGOs are formally implementing child labour-related development projects. Nevertheless, the Directory of Development Organizations suggests that there are more than 450 NGOs working in El Salvador. At least a fourth to a half of these organizations work with children, which suggests that at the very least 100 NGOs in El Salvador are handling the child labour issue in one form or another. My own experience confirms this supposition, as two of the three NGOs from my study are not included on the ILO list of NGOs working with child labourers in El Salvador. 
II.4 NGO coordination in the field of child labour - The expected contribution of my study

The existing research discussed above suggests that non-governmental work in the development field is thus far not coordinated to a great extent. Nevertheless, while some researchers commented on the negative impact of this reality on aid effectiveness, most researchers consider the lack of coordination to be harmless and in some cases even beneficial to development goals, as it might indicate the presence of innovation and tailoring of projects to particular local needs.

I aim to contribute to the existing pool of knowledge by focusing on a relatively controversial development topic of child labour - on which no agreement vis-à-vis the most appropriate approach exists thus far - and by examining how the mutual relations of NGOs working in this field affect the overall impact of their development assistance. With a view to the existing research, I expect to find that the NGOs examined do not coordinate their activities. However, it remains a matter of empirical investigation whether the overall impact of their work is consequently weakened, by duplicity, lack of cohesiveness, and a small scale of their projects, or rather strengthened, by providing a wide variety of 'remedies' to child labour closely adapted to the specific circumstances and needs of the aid recipients.

\section{Research Methods}

The findings reported in this paper are based on a case study of three development NGOs in El Salvador. I chose my cases from a pool of mid-size international NGOs that work with children; these requirements cut down the number of eligible organizations from the 450 Salvadoran NGOs mentioned above to approximately 30. I randomly picked five NGOs, emailed them in search of the project's support, and received three positive responses. I do not believe that the fact that I ended up examining only those NGOs that agreed to the 
collabouration introduced a major bias into the study, as the two NGOs that refused to work with me do not differ in external characteristics significantly from the three that I did study. It is more likely that the organizations declined due to a lack of time or manpower rather than due to a specific approach to child labour or to relations with other NGOs. In order to protect the NGOs' employees as well as their projects in El Salvador, I do not identify the organizations' by their real names. Instead, I use the following monikers: Alliance, Bond, and Closer.

I examined the three NGOs in person during two fieldwork trips. The first trip took place in January and February of 2007, while the second one in November 2010. I conducted both formal and informal interviews with the NGOs' employees and with the beneficiaries of their projects. I also interviewed several government and ILO workers. I supplemented the data obtained through interviews by participant observation as well as by the study of various documents produced by the NGOs.

The main goal of my data collection was to obtain information regarding two issues. First, I was trying to find out each NGO's approach to child labour along with the main factors underlying the specific ideological stance. Second, I aimed to discover whether and how the policies adopted towards child labour affected the NGOs' collabouration with one other and with other development NGOs.

\section{Discussion of Results}

This section first discusses how the NGOs under exploration view and work with child labourers and second how these positions might affect their mutual relations. 


\section{III.1 NGOs' approach to child labour}

In view of the contradictory opinions among researchers regarding how child labour should best be tackled, it is not surprising that each of the three NGOs studied has adopted a unique approach to dealing with child labour. A close analysis of the data gathered suggests that the specific choices might have been largely inspired by the NGOs' sources of funding and relations with other organizations ('mother' NGOs and the ILO).

\section{$\underline{\text { III.1a Alliance }}$}

Out of the three NGOs that I have studied, Alliance is the organization most closely aligned with the 'adaptive' side of the spectrum in its dealing with child labour. It is a midsize NGO loosely tied to a Western 'mother' $\mathrm{NGO}^{2}$ and 'sister' $\mathrm{NGOs}^{3}$ scattered primarily throughout Latin America. It does not cooperate closely with the ILO and obtains a large part of its funding through smaller private and often local donations. Both of these factors seem to make it more attuned to the poverty aspect rather than to the human-rights aspect of child labour.

Alliance has worked in El Salvador for almost half a century and its main activities revolve around the creation and operation of elementary schools, establishment of vocational training centers and travelling vocational workshops, promotion of integral child development from the earliest age, and street education. It does not have a formally defined child-labour policy and according to its director, it does not need one. When doing projects with children, the organization does not inquire if they are working and certainly does not discourage them from doing so. Rather, through the vocational training - open to all from the age of 10 - Alliance provides children with the tools to find better paid, safer, and more professional employment than the one in which they currently might be working. At the same

\footnotetext{
${ }^{2}$ By "mother" NGO, I refer to the founding NGO, most often somewhere in the Western world, which then went on to establish subsidiary branches in developing countries.

${ }^{3}$ By "sister" NGO, I mean the other subsidiary NGO branches in other developing countries.
} 
time, the NGO facilitates the children's school attendance, by providing them in their schools with free supplies and uniforms ${ }^{4}$. The overall impact of Alliance's work on the number of child labourers is not clearly negative. In fact, it is possible that the organization's work actually increases their number, as according to some Alliance's employees it is not uncommon that the organization's vocational workshops enable 12-13 year old children that were previously going to school and working part-time in agriculture to obtain full-time paid employment and hence abandon school attendance altogether.

In its stance towards child labour, Alliance is motivated by a belief that the phenomenon is a clear outcome of poverty and can be cured only through progressive economic development. In this conviction, it closely resembles the opinions of many child labourers and their parents in my study. When I interviewed several children that work in the extraction of mollusks -one of the 'worst' forms of Salvadoran child labour - along with their parents, they expressed the view that although the work is unpleasant or even outright repulsive, it constitutes their only means of earning enough money to provide sufficient food for the whole family. Moreover, they pointed out that several years of schooling were not going to make any difference in their lives and thus school attendance was perhaps not helpful in any way. While the belief in the futility of education is likely short-sighted, in this instance the work of Alliance that would provide the child labourers with a different set of vocational skills could be very helpful.

Alliance's approach to child labour differs greatly from that of the ILO as well as from the official stance of the government. However, as the organization does not work closely with the ILO and its projects are quite small-scale, it has not attracted any criticism or even attention of the ILO or of any other child-labour-abolitionist organizations. Moreover, the NGO obtains a large portion of its funding from private donations and church organizations

\footnotetext{
${ }^{4}$ This activity might be of less importance since the 2011 inception of the governmental Let's Go to School program, which provides free school supplies, uniforms, and meals to all poor children attending public schools
} 
and thus its projects do not often come under the scrutiny of official aid agencies. Finally, Alliance does not diverge in its approach far from some social welfare programs operated by the Salvadoran government itself, particularly from the Red Solidaria, which provides cash transfers to poor families without inquiring whether their children are economically active. However, even if the government were strictly enforcing the existing bans on child labour in its own programs and projects, it does not monitor NGO projects closely enough to know their exact content and ban them in case they are contrary to Salvadoran national policies.

\section{$\underline{\text { III.1b Bond }}$}

In its child-labour policies, Bond finds itself situated somewhere in between the 'adaptive' and the 'abolitionist' approach. The organization forms part of an NGO family that is both larger and more globally present than Alliance's. That is probably one of the reasons why Bond receives a larger part of its funding from official aid agencies and from its Western 'mother' NGO than from private donations and why it has closer ties with the ILO. Consequently, the organization formally subscribes to the abolitionist rhetoric regarding child labour; nevertheless, it does not strictly enforce such policies in its projects.

Bond has been working in El Salvador since the 1970s and it focuses on all aspects of life crucial to children's development including health, education, economic development, environmental conservation, and infrastructure. It works in communities where it provides primary health care for children and youth, educational support to local schools, human rights advocacy (primarily against child abuse), and economic support to the children's parents.

The activities with the most likely impact on child labour are Bond's work in education and in economic development. Until recently, Bond used to encourage school attendance among children through the provision of school supplies and uniforms. Nevertheless, as the government stepped in to fill this role with the Let's Go to School program, the NGO now 
focuses more on making the Salvadoran school system more flexible and better able to prepare students for entry into the labour force, by providing training to teachers and modern supplies to schools. Through these efforts, Bond is trying to encourage and make it possible for children to stay in school, even alongside their jobs.

In the field of economic development, Bond provides the parents of the children with whom it works with vocational training workshops, business workshops, and micro-loans. The vocational training workshops help people gain new skills and thus find jobs more lucrative than working in agriculture, primarily as bakers, tailors, auto-mechanics, and electro-technicians. The business workshops on the other hand aspire to equip people with the skills necessary to open their own businesses, such as in accounting, finance, commerce, and marketing strategies. People who successfully finish the business workshops qualify to receive a micro-loan at a zero interest rate that is supposed to enable a launch of the small business in mind. The common goal of these initiatives is to increase the earning potential of the children's parents and hence make it possible for their children to focus more on school and to work less.

With the two activities discussed above, Bond addresses primarily the poverty-side of child labour; however, the organization also gives some credit to the 'abolitionist' side of the argument that advocates against the phenomenon as intrinsically harmful to children's development. Thus, while Bond does not condition the participation in its programs on child labourers ceasing to work, it attempts to make it possible for children to stop working not only through increasing their parents' incomes and through making schooling more relevant and flexible, but also through raising parental awareness of the possibly detrimental impact of labour on their children. It also formally disapproves of child labour, particularly of its 'worst' forms. 
This middle-of-the-spectrum approach to child labour fits well with Bond's position vis-àvis its relations with the ILO and its sources of funding. The organization collabourates in some projects with the ILO and has received funding from it in the past. Bond also receives a certain portion of its funding from the US government, which is very abolitionist in its view of child labour. Such sources of collabouration would probably not be possible without Bond's formally verbalized stance against child labour. At the same time, Bond's 'mother' NGO, which is also its most important source of funding, considers child labour to be primarily a product of poverty and does not emphasize bans against it. Consequently, it is easier to understand why Bond's formal position against child labour is not always executed in practice.

\section{$\underline{\text { III.1c Closer }}$}

Out of the three NGOs examined, Closer is the organization most 'abolitionist' in its treatment of child labour. Even though it is a somewhat smaller NGO than Bond, both in El Salvador and more globally, it cooperates more closely with the ILO and receives a large majority of its funding from the US Government ${ }^{5}$. Consequently, Closer formally proclaims that child labour is highly undesirable, internationally illegal, and gravely detrimental to development. Moreover, unlike Bond, Closer also follows through with the abolitionist approach in its projects and policies.

Closer has been working in El Salvador for almost sixty years, longer than either Alliance or Bond. Among its main areas of focus are health, education, democracy and governance support, and emergency response. The activities most acutely geared towards tackling child labour are the educational ones.

\footnotetext{
${ }^{5}$ The US Government, as I have mentioned previously, is very abolitionist in its view of child labour.
} 
Within these activities, Closer has tried to develop a two-pronged approach in its efforts to eradicate child labour. On one hand, the organization regards the Salvadoran educational system as rigid, ineffective, and incapable of providing many graduates with the skills necessary to obtaining a decent job and attempts to address these deficiencies with various own projects. For example, Closer affords some of its beneficiaries with the support to send their children to pre-schools, which in the organization's view increase the children's likelihood of finishing elementary school. For older children, Closer organizes afternoon study-halls, where its employees provide help with schoolwork to students lagging behind, many of them (former) child labourers. With these activities, Closer hopes to increase the rate of students that remain in school and hence indirectly decrease the number of children that work.

On the other hand, Closer also conducts activities that aim to eliminate child labour more directly. First, it raises awareness about the harmful nature of child labour among both students and children's parents. In a belief that many children work because their parents consider it a beneficial experience rather than purely due to poverty, the organization's employees often visit children's parents (in their projects) to talk to them about other options of increasing income that would allow their children not to work and focus purely on education. One of the employees interviewed mentioned a case of a Salvadoran fisherman with two sons, an eight and a ten-year-old, who did not attend school but went fishing with their father every day. Following Closer's intervention, the father sent the two sons to school and spent every day six, instead of three, hours at sea, earning the same amount as previously. While this example sounded somewhat unusual, as most child labourers interviewed indicated a real necessity to work due to their families' dire poverty, it is possible that in some - or maybe even many - cases, children's remuneration could be compensated by their parents' increasing their working hours. Second, while Closer does not have the power to 
issue sanctions to the parents of child labourers directly, it sometimes cooperates with the ILO in identifying children working in the 'worst' forms of child labour and notifying the relevant authorities about the fact.

Closer's 'abolitionist' approach to child labour corresponds well with its relations with the ILO and with its sources of funding. Many Closer's programs were conceived of in direct cooperation with the ILO and receive ILO funding. As a result, Closer's education and awareness-raising projects are generally larger in scale than Alliance's and Bond's. Furthermore, more than 70 per cent of Closer's funding comes from the US Government, a strong supporter of the abolitionist approach to child labour. Both the ILO and USAID funds would probably be compromised if Closer did not adhere more-or-less to the same view of child labour as the organizations themselves advocate.

Table 1. The NGO's Views on Child Labour, Ties with Other Organizations, and Sources of Funding

\begin{tabular}{c|l|l|l}
\hline NGO & \multicolumn{1}{|c|}{$\begin{array}{c}\text { Approach to Child } \\
\text { Labour }\end{array}$} & $\begin{array}{l}\text { Relationships with Other } \\
\text { Institutions/ Mother NGOs }\end{array}$ & \multicolumn{1}{c}{ Funding } \\
\hline Alliance & $\begin{array}{l}\text { Close to an Adaptive } \\
\text { approach }\end{array}$ & $\begin{array}{l}\text { Out of the three, the most } \\
\text { "locally based" NGO, only } \\
\text { loosely connected to its } \\
\text { "mother" and "sister" NGOs and } \\
\text { has no relations with the ILO }\end{array}$ & $\begin{array}{l}\text { Funding raised mostly } \\
\text { privately and from church } \\
\text { institutions }\end{array}$ \\
\hline Bond & $\begin{array}{l}\text { Somewhere between an } \\
\text { Adaptive and an } \\
\text { Abolitionist Approach }\end{array}$ & $\begin{array}{l}\text { Some ties and cooperation with } \\
\text { the ILO, relations with "mother" } \\
\text { and "sister" NGOs stronger than } \\
\text { Alliance }\end{array}$ & $\begin{array}{l}\text { Half the funding obtained } \\
\text { from small private donations, } \\
\text { the other half from official } \\
\text { donor agencies, including the } \\
\text { US Government }\end{array}$ \\
\hline Closer & $\begin{array}{l}\text { Close to an Abolitionist } \\
\text { approach }\end{array}$ & $\begin{array}{l}\text { Strong links both with the ILO } \\
\text { and the US government; in } \\
\text { many projects collaborates with } \\
\text { the ILO and the Salvadoran } \\
\text { government. In terms of the } \\
\text { relationship to the "mother" } \\
\text { NGO, Closer is the least } \\
\text { autonomous out of the three } \\
\text { NGOs examined }\end{array}$ & $\begin{array}{l}\text { Closer obtains more than 70 } \\
\text { per cent of its funding from } \\
\text { the US government, the rest } \\
\text { comes from the ILO and } \\
\text { private donations }\end{array}$ \\
\hline
\end{tabular}




\section{III.2 Relations among the NGOs and how they are affected by their stance on child labour}

Interviews conducted with the three NGOs' employees indicated that the organizations not only do not collabourate in their projects that touch on child labour, they do not communicate either and some do not even know of the others' existence. For example, neither Bond nor Closer knew of Alliance. Bond and Closer were familiar with each others' names, but only Bond was aware that Closer was working on child-labour issues, not vice versa ${ }^{6}$. That knowledge, however, did not inspire Bond to attempt to collabourate with Closer on its own child-labour project. This lack of coordination and communication most likely extends beyond Alliance, Bond, and Closer to other NGOs working on child issues in El Salvador, as none of the three NGOs examined mentioned being involved in any significant cooperation with any other NGO in the country.

The finding that the three NGOs do not coordinate their activities was expected; nonetheless, as I have stated earlier, it remained a matter of empirical analysis to determine whether the overall impact of such non-coordination was positive or negative. The possibly negative effects in this case seem clear. By working alone, the projects of the NGOs that I examined are small in scale as well as in duration, which certainly diminishes their potential impact. Moreover, it is possible that the NGOs duplicate their efforts - where for instance both Alliance and Bond offer school supplies to children from the same family. While to my knowledge this has not in fact occurred, one can easily imagine that it could happen as the organizations do not talk to each other and people receiving benefits are not likely to turn them down, even if they have received similar benefits from another organization already. The potentially positive effects of the non-coordination could involve tailoring of the small NGO projects to suit exactly the needs of the particular recipients, which would perhaps not be possible with projects of larger size coordinated from far away. Unfortunately, none of the

\footnotetext{
${ }^{6}$ This was probably the case because Closer was working with the ILO and thus its projects were more visible.
} 
data that I collected suggested that any of the three NGOs designed their child-labour projects based on significant input from the project recipients. Rather, the approach adopted seemed to be dictated more by the sources of funding on which the NGO relied and on the closeness of its ties with the ILO.

This point leads me to the most disappointing and disturbing finding that emerged from the data analysis. The NGOs seem to be working at cross-purposes with regard to the issue of child labour and thus might be completely annulling the results of each other's work. Alliance does not see bans against even the worst forms of child labour as productive and Closer does its outmost to encourage parents and employers to respect such bans. Thus, one can easily picture an occurrence in which one family's children are first taken away from their jobs in response to Closer's pressure and subsequently sent for vocational training and straight back into the labour market by Alliance. Such a situation probably never actually arose, since Alliance, Bond, and Closer work in different parts of El Salvador. There are many other NGOs in the country working on children's issue, though, with approaches to child labour that cover the full spectrum between 'adaptive' and 'abolitionist', and hence it is very possible that their activities and projects did in fact go against each other at some point. However, even if such a situation never actually occurred, the fact that the divergent approaches to child labour are contradictory and work against each other is a reality.

The clashing nature of the child-labour projects has at least two detrimental effects. First, it undoubtedly decreases the overall effectiveness of aid dedicated to the issue, in the least from the donors' perspective, as some children are trained and encouraged to work and perhaps as a result abandon schooling while other children are banned from working and sent back to school. The second and even more worrisome negative impact is that the decision whether a particular child will be offered vocational training or school support is not decided upon with a view to his/her circumstances and abilities but rather based on which of the 
various NGOs happens to work in his/her area and to what ideology regarding child labour it happens to ascribe. Thus, based on the data available, it is all but impossible to draw a different conclusion than that the aid provided by NGOs' in El Salvador in the controversial issue of child labour seems to be of little effectiveness at best and appears to lack any serious accountability to its recipients.

\section{Conclusion}

The purpose of this paper has been to contribute to the existing literature on aid effectiveness by examining how mutual relations among Salvadoran NGOs working in the divisive development topic of child labour affect the overall impact of their projects. Extant research has indicated that similar to aid provided by official development agencies, NGO aid also tends to be relatively uncoordinated. Nevertheless, while some authors found this lack of coordination to be harmful to the NGOs' development goals, others concluded that it did not bear any negative effect or could be even beneficial. With a view to these findings, I expected to discover that the NGOs that I studied did not coordinate their child-labour projects but whether it was for the good or for the bad remained a matter of empirical investigation.

Analysis of the data that I collected during my examination of the work of three organizations in El Salvador - Alliance, Bond, and Closer - suggested that the NGOs not only did not coordinate their child-labour activities, their preferred approaches to the issue of child labour were at cross-purposes and thus were essentially annulling each other's efforts. Based on an examination of the NGOs' funding sources and relations with other organizations, I discovered that NGOs with close links to the ILO were more likely to support a complete eradication of child labour, while NGOs with more local links and private funding viewed child labour as an inevitable result of economic poverty and hence were opposed to its bans. More importantly, however, and regardless of the source of their child-labour 
ideology, the divergent approaches to child labour have led the NGOs to work against each other in the realm of this development issue, which inevitably must have decreased their effectiveness. If one NGO pressured parents to withdraw their children from the workplace while another offered children of the same age vocational training with the aim of finding a job, the money used to fund the development activities was surely not being used in the most efficient way. Even more troubling is that neither the parents nor the children involved seemed to have had much of a say over the design of the projects and their specific activities.

This paper does not attempt to offer the ideal remedy to the problem described. Rather, it intends to foremost draw greater attention to the fact that the lack of coordination among NGOs might be very inefficient with respect to the donor funds used and harmful to the aid recipients. One solution could be to encourage a greater level of cooperation and coordination among NGOs through the creation of a coordinating body at the national level in El Salvador that would attempt to delineate one common approach to child labour and divide the various NGO activities within the country to support a more efficient division of labour. Of course, one would need to make sure that the domestic populace receiving the 'benefits' of the NGO work would be sufficiently involved in the identification of the most suitable approach to the issue. Alternatively, the government could define a recommended approach to child labour and ensure that all NGOs either followed it or at least not worked against it. No solution is likely to be flawless; nevertheless, the current situation - which is probably occurring in many developing countries, not just in El Salvador, and in many development topics, not only in child labour - is inefficient and unsustainable and hence awareness of it and subsequent action are required. 


\section{References}

Acharya, Arnab, de Lima, A. Fuzzo and Moore, Mick (2003), 'The Proliferators: Transactions Costs and the Value of Aid', Institute of Development Studies.

Basu, Kaushik and Hoang Van, Pham (1998), 'The economics of child labour', American Economic Review, pp. 412-427.

Bhalotra, Sonia and Heady, Christopher (2003), 'Child farm labour: The wealth paradox', The World Bank Economic Review, Vol. 17, No. 2, pp. 197-227.

Bigsten, Arne (2006), 'Donor coordination and the uses of aid', Working Papers in Economics, Vol. 196.

Deb, Partha and Rosati, Furio (2004), 'Estimating the effect of fertility decisions on child labour and schooling', Understanding Children's Work (UCW) Working Paper.

Dessy, Sylvain E. and Pallage, Stephane (2004), 'A Theory of the Worst Forms of Child Labour', The Economic Journal, Vol. 115, No. 500, pp. 68-87.

Development Assistance Committee (2005), The Paris Declaration on Aid Effectiveness, Paris, France: Organization for Economic Cooperation and Development.

Development Assistance Committee (2007), The Accra Agenda for Action, Accra, Ghana: Organization for Economic Cooperation and Development.

Easterly, William (2002), 'The Cartel of Good Intentions: The Problem of Bureaucracy in Foreign Aid', Policy Reform, Vol. 5, No. 4, pp. 223-250.

Edi, Jepri and Setianingtias, Ayu (2007), 'Donor proliferation and donor coordination in Indonesia: the case of governance reform', Centre for the Future State, Institute of Development Studies, University of Sussex.

Frot, Emmanuel and Santiso, Javier (2009), 'Crushed aid: fragmentation in sectoral aid', OECD Working Paper, Vol. 284. 
International Labour Organization (1973), Convention Concerning the Minimum Age for Admission to Employment, No. 138.

International Labour Organization (1999), Convention Concerning the Prohibition and Immediate Action for the Elimination of the Worst Forms of Child Labour, No. 182.

International Labour Organization (2013), 'Child Labour', Accessed April 15, 2013. http://www.ilo.org/global/topics/child-labour/lang--de/index.htm

Knack, Stephen and Rahman, Aminur (2004), 'Donor Fragmentation and Bureaucratic Quality in Aid Recipients', Background Paper to World Development Report 2004, Washington, DC.

Lawson, Marian Leonardo (2010), Foreign Aid Reform: Agency Coordination, Washington, DC: DIANE Publishing.

McCoskey, Suzanne (2009), 'NGOs in the Aid Community: Do Funding Source or Economic Conditioning Matter to Decisions of Country or Activity Involvement', Journal of Humanitarian Assistance.

Ministerio de Economía del Salvador (2010), Midiendo el Trabajo Infantil en la Encuesta de Hogares de Propósitos Múltiples, EHPM -2009.

Moore, Spencer, Eng, Eugenia and Daniel, Mark (2003), 'International NGOs and the role of network centrality in humanitarian aid operations: A case study of coordination during the 2000 Mozambique floods', Disasters, Vol. 27, No. 4, pp. 305-318.

Morss, Elliott R (1984), 'Institutional destruction resulting from donor and project proliferation in Sub-Saharan African countries', World Development, Vol. 12, No. 4, pp. 465-470.

Öhler, Hans and Nunnenkamp, Peter (2012), 'Funding, Competition and the Efficiency of NGOs: An Empirical Analysis of Non-charitable Expenditure of US NGOs Engaged in Foreign Aid', Kyklos, Vol. 65 No.1, pp. 81-110. 
Oxfam, Great Britain (2000), Development, NGOs, and Civil Society.

Paris, Roland and Sisk, Timothy D. (2009), The dilemmas of statebuilding: confronting the contradictions of post-war peace operations, London, UK: Taylor and Francis.

Pfeiffer, James (2003), 'International NGOs and primary health care in Mozambique: the need for a new model of collaboration', Social Science and Medicine, Vol. 56, No. 4, pp. 725-738.

Scott, Colin D. and Hopkins, Raul (1999) 'The Economics of Non-Governmental Organisations,' The Development Economics Discussion Paper Series Vol. 15, The London School of Economics.

Swinnerton, Kenneth A. and Rogers, Carol Ann (1999), 'The economics of child labour: Comment', The American Economic Review, Vol. 89, No.5, pp. 1382-1385.

Telford, John and Cosgrove, John (2007), 'The international humanitarian system and the 2004 Indian Ocean earthquake and tsunamis', Disasters, Vol. 31, No.1, pp. 1-28.

United States Department of Labour (2012), Child Labour in El Salvador. http://www.dol.gov/ilab/programs/ocft/2011TDA/ElSalvador.pdf.

Volz, Carsten (2005), 'Humanitarian coordination in Indonesia: an NGO viewpoint', Forced Migration Review, Vol. 18, pp. 26-27. 